\title{
Model Development for Single Substrate Polycyclic Aromatic Hydrocarbon Biodegradation
}

\author{
N.Othman ${ }^{1}$, S. Abdul-Talib², A. Yassin ${ }^{3}$ \\ 1. Micropollutant Research Centre,
}

Faculty of Civil and Environmental Engineering, University Tun Hussein Onn, Beg Berkunci 101,

86400 BatuPahat, Johor, Malaysia

Faculty of Civil Engineering, University Technology Mara, Shah Alam, Selangor.

Faculty of Civil Engineering, University Technology Malaysia

norzila@uthm.edu.my

Keywords: Biodegradation, bacteria,PAH

\begin{abstract}
The kinetic of microbial growth and substrate utilization can be used to predict the fate and behavior of contaminants like PAHs in the environment through appropriate models. Further kinetic study results are useful in evaluating and weighing suitable treatment option for remediation and clean up of contaminated sites.. In this research a mathematical model for biodegradation of PAHs using isolated bacteria from municipal sludge was studied.. The model was developed using the Monod equation.. Results showed that the remaining PAHs in all samples decreased within time.
\end{abstract}

\section{Introduction}

Biodegradation kinetics can reveal the dependence of substrate or contaminant depletion with time. Growth and substrate depletion data may fit to a simple Monod model as stated in Equation 1.[1], [2].

$$
\mu=\frac{\mu_{\max } \mathrm{S}}{\mathrm{K}_{\mathrm{s}}+\mathrm{S}}
$$

Where $\mu=$ specific growth rate $(1 / \mathrm{h}) ; \mu_{\max }=$ maximum specific growth rate $(1 / \mathrm{h}) ; \mathrm{S}=$ substrate concentration $(\mathrm{mg} / \mathrm{L}) ; \mathrm{K}_{\mathrm{s}}=$ affinity constant $(\mathrm{mg} / \mathrm{L})$;

This model is known as the sole substrate Monod model which can be described as a nointeraction model. The equation describing sole substrate kinetics for an organic compound can be represented as

$$
\begin{aligned}
& \mathrm{r}_{\mathrm{s}}=\underset{\text { or }}{\mathrm{q}_{\max } \frac{\mathrm{X}_{0} \mathrm{~S}}{\mathrm{~K}_{\mathrm{s}}+\mathrm{S}}} \\
& \frac{\mathrm{dS}}{\mathrm{dt}} \frac{\mathrm{q}_{\max } \mathrm{X}_{0} \mathrm{~S}}{\mathrm{~K}_{\mathrm{s}}+\mathrm{S}}
\end{aligned}
$$

Where $\mathrm{r}_{\mathrm{s}}$ and $\mathrm{dS} / \mathrm{dt}=$ substrate disappearance rate; $\mathrm{q}_{\max }=$ maximum substrate utilization rate; $\mathrm{X}_{0}=$ initial biomass concentration

This model assumes that the presence of other substrates does not affect the behavior of a single substrate. It represents the case where a compound in a mixture may behave as if it is the only compound present not accounting for the effects resulting from other existing substrates. Equation (3) assumes that the PAH is transformed by a common enzyme pathway[1] [3]. 
The above equation is predictive since it rely on the parameters obtained from the sole substrate experiments. Enhanced degradation resulting from biomass proliferation will not be accounted. It is assumed that the biomass concentration will remain constant throughout the experiment.

\section{Materials and method}

The parameters obtained from the sole substrate experiments formed a basis for modeling. The experimental data consisted of initial substrate concentration over a given sampling period. The value of initial concentration of PAHs in this experiment is $100 \mathrm{mg} / \mathrm{l}$.

Tha values of affinity constant $\left(\mathrm{K}_{\mathrm{s}}\right)$ for all PAHs were adopted from literature and given in Table 1 . According to Alexander [4], the $\mathrm{K}_{\mathrm{s}}$ value for single substrate depend on the type of the substrate.

Table 1: Affinity constant value of PAHs

\begin{tabular}{|l|c|}
\hline \multicolumn{1}{|c|}{ Growth substrate } & Affinity constant, $\mathrm{K}_{\mathrm{s}}(\mathrm{mg} / \mathrm{l})$ \\
\hline Napthalene & 0.0750 \\
Acenapthylene & 0.0050 \\
Acenapthene & 0.0045 \\
Fluorene & 0.0043 \\
Phenanthrene & 0.0035 \\
Anthrecene & 0.0020 \\
\hline
\end{tabular}

(Value of affinity constant adopted from: Desai [5] \{napthalene \& fluorene\}; Guha et al.,[6] \{phenanthrene\}; Grady et al[7] \{acenapthylene, acenapthene \& anthracene\})

The values of maximum substrate utilization rate were determined through curve fitting. The established values from curve fitting for maximum substrate utilization $\left(\mathrm{q}_{\max }\right)$ were $0.0100 \mathrm{mg}$ substrate $/ \mathrm{mg}$ biomass $/ \mathrm{h}, 0.0050 \mathrm{mg}$ substrate $/ \mathrm{mg}$ biomass $/ \mathrm{h}, 0.0045 \mathrm{mg}$ substrate $/ \mathrm{mg}$ biomass $/ \mathrm{h}$, $0.0043 \mathrm{mg}$ substrate $/ \mathrm{mg}$ biomass $/ \mathrm{h}, 0.0030 \mathrm{mg}$ substrate $/ \mathrm{mg}$ biomass $/ \mathrm{h}, 0.0025 \mathrm{mg}$ substrate $/ \mathrm{mg}$ biomass $/ \mathrm{h}$ for napthalene, acenapthylene, acenapthene, fluorene, phenanthrene and anthracene respectively.

The initial biomass concentration $\left(\mathrm{X}_{0}\right)$ was also determined through curve fitting. The initial biomass concentration established through this method were $50 \mathrm{mg} / 1,75 \mathrm{mg} / 1,90 \mathrm{mg} / 1,95 \mathrm{mg} / 1$, $97 \mathrm{mg} / 1$ and $100 \mathrm{mg} / 1$ for napthalene, acenapthylene, acenapthene, fluorene, phenanthrene and anthracene respectively.

The Monod equation can be linearized and the coefficients can be estimated using linear regression analysis. Linearized forms of the Monod equation is represented in the form of Lineweaver Burk. A simple linear regression is not a proper technique for a non-linear equation because it generates for error in a distribution. An accurate method of analysis for a non linear equation should involve using a non linear regression technique .

The Monod parameters can be estimated by solving the homogenous differential equation using numerical application. The numerical integration of the differential equations is commonly achieved using a fourth order Runge Kutta algorithm. Runge Kutta methods take into account an improved slope average which predicts the values more accurately.

The sole substrate parameter was estimated for PAHs degradation using the isolated strains. The constants associated with biotic and abiotic losses are assumed to be negligible. The mass balance equation representing the sole substrate system is given by Equation (3).

The fourth order Runge - Kutta method was used for fitting the Monod equation to the experimental data. The fourth order Runge-Kutta method is represented as Equation (4)

$$
\mathrm{S}=\mathrm{S}_{0}+1 / 6\left(\mathrm{~K}_{1}+2 \mathrm{~K}_{2}+2 \mathrm{~K}_{3}+\mathrm{K}_{4}\right) \mathrm{dt}
$$

Where $\mathrm{K}_{1}=\mathrm{q}_{\max } \mathrm{S}_{0} \mathrm{X}_{0} / \mathrm{K}_{\mathrm{s}}+\mathrm{S}_{0} ; \quad \mathrm{K}_{2}=\mathrm{q}_{\max }\left(\mathrm{S}_{0}+0.5 \mathrm{~K}_{1} \mathrm{dt}\right) ; \quad \mathrm{K}_{3}=\mathrm{q}_{\max }\left(\mathrm{S}_{0}+0.5 \mathrm{~K}_{2} \mathrm{dt}\right.$; and $\mathrm{K}_{4}=\mathrm{q}_{\max }\left(\mathrm{S}_{0}+\right.$ $\mathrm{K}_{3} \mathrm{dt}$ ) 
All calculations were performed using Matlab7.8 as written in program script in Table 2. In this study program script in Table 2 was applied to solve on The fourth Runge-Kutta method.

Table 2: Program script written in Mathlab

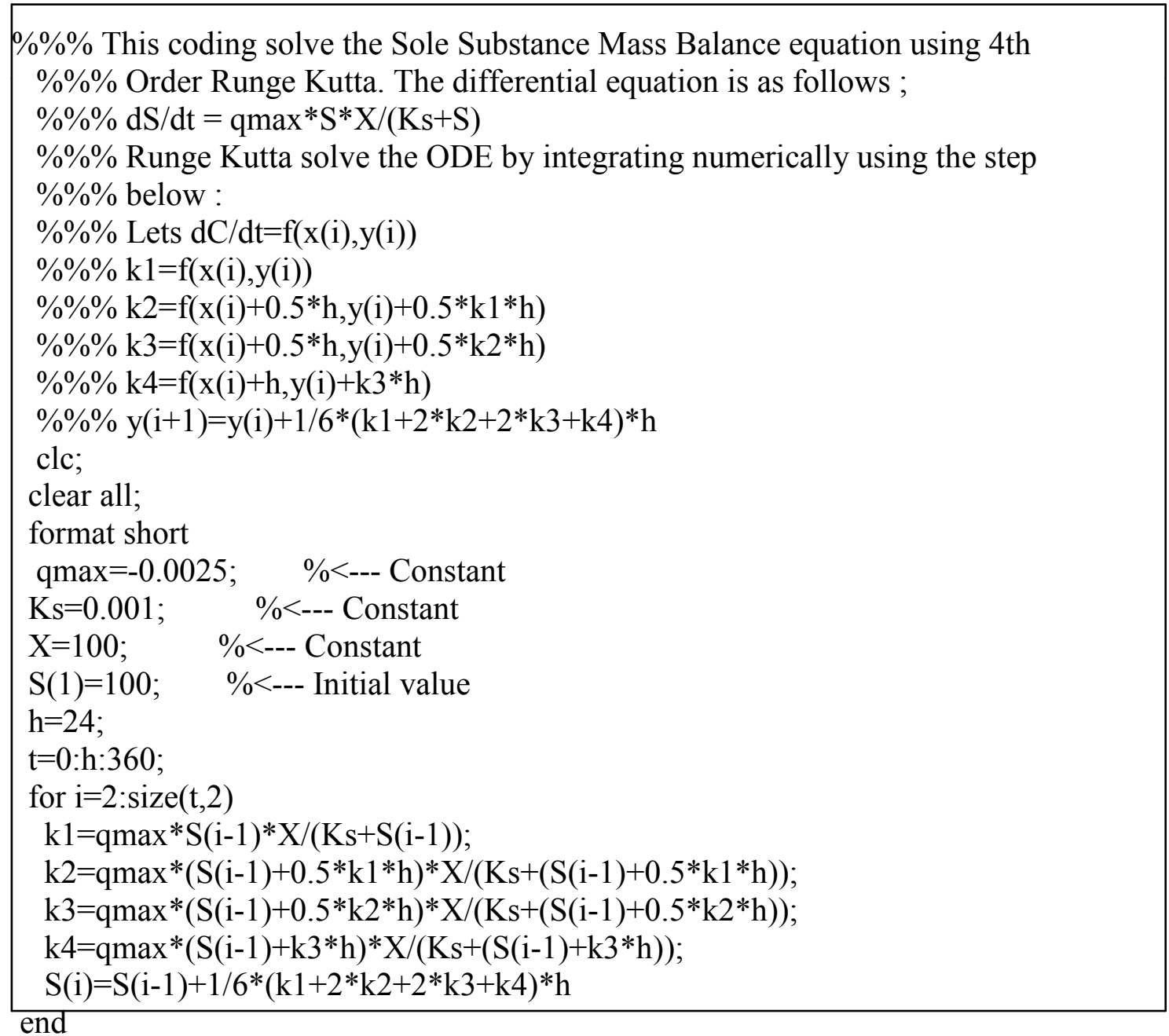

\section{Results and Discussion}

Substrate depletion data was generated for the individual PAHs of napthalene, acenapthylene, acenapthene, fluorene, phenanthrene and anthracene. An experimental observation was used to evaluate the proposed model.

To calibrate the model, one of the PAHs namely, phenanthrene was used to determine model parameters $\mathrm{q}_{\max }$ and $\mathrm{X}_{0}$ by curve fitting. These model parameters together with $\mathrm{K}_{\mathrm{s}}$ and $\mathrm{S}_{\text {initial }}$ were used to simulate the remaining. phenanthrene. The model was calibrated using five sets of data and example of data as shown in Table 2. In this paper only model for phenanthrene was discussed.

The simulated and measured PAHs corresponding to these parameters is shown in Figure.1. The average error show the difference between values of substrate concentration for the experiments and model predicted. The lowest average of error squares show the best data set that predic the fitting values. The results show that the best fitting value for $\mathrm{q}_{\max }$ and $\mathrm{X}_{0}$ of phenanthrene are $0.0030 \mathrm{mg}$ substrate/mg biomass/h and $97 \mathrm{mg} / \mathrm{l}$ respectively as shown in Figure 1 . The simulation from data set one resulted in the lowest error square with the average value is 0.5041 . 
Table 3: An example of sole substrate parameter estimation

\begin{tabular}{|c|c|c|c|c|c|c|c|c|c|}
\hline PAHs & $\begin{array}{c}\mathrm{S}_{\text {initial }} \\
(\mathrm{mg} / \mathrm{l})\end{array}$ & $\begin{array}{c}\Delta \mathrm{t} \\
\text { (hour) }\end{array}$ & $\begin{array}{c}\mathrm{K}_{\mathrm{s}} \\
(\mathrm{mg} / \mathrm{l})\end{array}$ & $\begin{array}{c}\mathrm{q}_{\max } \\
(\mathrm{mg} \\
\text { substrate/mg } \\
\text { biomass/h) }\end{array}$ & $\begin{array}{c}\mathrm{X}_{0} \\
(\mathrm{mg} / \mathrm{l})\end{array}$ & $\begin{array}{c}\mathrm{S}_{\text {final }} \\
\text { (predicted) } \\
(\mathrm{mg} / \mathrm{l})\end{array}$ & $\begin{array}{c}\mathrm{S}_{\text {final }} \\
\text { (observed) } \\
(\mathrm{mg} / \mathrm{l})\end{array}$ & $\begin{array}{c}\text { Error } \\
\mathrm{S}_{\text {observed }} \\
\mathrm{S}_{\text {predicted }}\end{array}$ & $\begin{array}{c}\text { Error } \\
\text { square }\end{array}$ \\
\hline Phenanthrene & $\begin{array}{l}100 \\
100 \\
100 \\
100 \\
100 \\
100 \\
100 \\
100 \\
100 \\
100 \\
100\end{array}$ & $\begin{array}{c}24 \\
48 \\
72 \\
96 \\
120 \\
144 \\
168 \\
216 \\
264 \\
312 \\
360 \\
\end{array}$ & $\begin{array}{l}0.0035 \\
0.0035 \\
0.0035 \\
0.0035 \\
0.0035 \\
0.0035 \\
0.0035 \\
0.0035 \\
0.0035 \\
0.0035 \\
0.0035\end{array}$ & $\begin{array}{l}-0.0030 \\
-0.0030 \\
-0.0030 \\
-0.0030 \\
-0.0030 \\
-0.0030 \\
-0.0030 \\
-0.0030 \\
-0.0030 \\
-0.0030 \\
-0.0030\end{array}$ & $\begin{array}{l}97 \\
97 \\
97 \\
97 \\
97 \\
97 \\
97 \\
97 \\
97 \\
97 \\
97\end{array}$ & $\begin{array}{l}93.16 \\
86.32 \\
79.48 \\
72.64 \\
65.80 \\
59.17 \\
52.12 \\
38.44 \\
24.76 \\
16.86 \\
12.20\end{array}$ & $\begin{array}{l}93.45 \\
86.59 \\
80.19 \\
73.21 \\
66.23 \\
59.33 \\
52.62 \\
38.72 \\
25.11 \\
17.11 \\
12.21\end{array}$ & $\begin{array}{l}0.29 \\
0.27 \\
0.71 \\
0.57 \\
0.43 \\
0.16 \\
0.50 \\
0.28 \\
0.35 \\
0.25 \\
0.01 \\
3.82 \\
0.35\end{array}$ & $\begin{array}{l}0.0841 \\
0.0729 \\
0.5041 \\
0.3249 \\
0.1849 \\
0.0256 \\
0.2500 \\
0.0784 \\
0.1225 \\
0.0625 \\
0.0001 \\
1.7100 \\
0.5041\end{array}$ \\
\hline
\end{tabular}

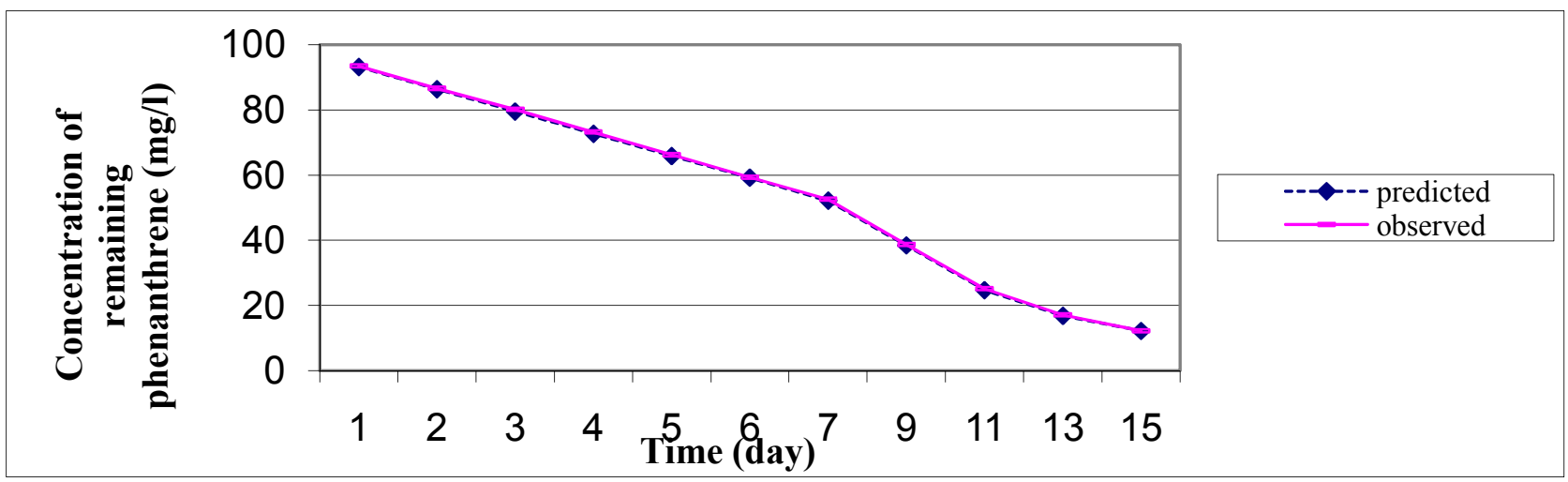

Figure 1: Concentration of remaining phenanthrene predicted and observed for data set one

Table 4: Estimated parameters for degradation of individual PAHs

\begin{tabular}{|c|c|c|c|c|c|c|}
\hline Parameters & Napthalene & Acenapthylene & Acenapthene & Fluorene & Phenanthrene & Anthracene \\
\hline $\mathrm{q}_{\max }$ & 0.0100 & 0.0050 & 0.0045 & 0.0043 & 0.0030 & 0.0025 \\
$\mathrm{~K}_{\mathrm{s}}$ & 0.075 & 0.045 & 0.022 & 0.017 & 0.012 & 0.010 \\
$\mathrm{q}_{\max } / \mathrm{K}_{\mathrm{s}}$ & 0.13 & 0.11 & 0.20 & 0.25 & 0.25 & 0.25 \\
\hline
\end{tabular}

Napthalene has the highest affinity constant while anthracene exhibits the lowest affinity constant. Anthracene with the lowest affinity constant indicates that this substrate poses the grearest binding strength towards the enzyme of PAHs degrading bacteria [8]. At lower values of the $\mathrm{K}_{\mathrm{s}}$, the substrate is in the form of the enzyme substrate complex indicating that the half maximum degradation rate will be achieved at a lower concentration of the substrate [9]. Napthalene exhibits highest enzyme affinity constant suggesting a low binding strength. The $\mathrm{K}_{\mathrm{s}}$ value for all six PAHs were below the initial concentration used in the experiments.

This study also suggested that the concentration of initial biomass of PAHs degrading bacteria are in the range of $50 \mathrm{mg} / 1$ to $100 \mathrm{mg} / 1$ to degrade PAHs with the initial concentration of $100 \mathrm{mg} / \mathrm{l}$.

Biodegradation can be defined as the biologically catalyzed reduction in complexity of chemicals. In the case of PAHs, PAHs degrading bacteria generally used PAHs as a carbon and energy source. The degradation of PAHs by bacteria involve cleaving processes of the PAHs aromatic ring by dioxygenase enzyme. Biodegradation of PAHs is subjected to a variety of physical, chemical and biological factor that influence the degradation rate. Two of the important factors in predicting the remaining PAHs concentration in the environment are concentration of PAHs as pollutant and concentration of biomass at the polluted areas. 
Conclusion Determining degradation rates experimentally and those factors influencing them will enhance our understanding of the persistence, recalcitrance and transformation of contaminants in natural and engineered systems providing us the tools to design effective treatment system.

\section{References}

[1] Monod, J (1949). The Growth of bacterial cultures. Annu Rev. Microbial., 3, 371-394.

[2] Mrozik, A.,Piotrowska-Seget,Z., Labuzek, S .(2003). Bacterial degradation and bioremediation of polycyclic aromatic hydrocarbon. Polish journal of Environmental Studies. 12(1), 15-25.

[3] Rakesh, K.J., Manisha,K., Sumeet, L, Banwari, L.(2005). Microbial diversity: Application of microorganism for biodegradation of xenobiotic. Current Science. 89, 101-112.

[4] Alexander, M. (1999). Biodegradation and Bioremediation. Academic Press London.

[5] Desai, A.M., Biodegradability of selected polycyclic aromatic hydrocarbon. Master thesis. Texas University

[6] Guha,S., Peters,C.A., Jaffe, P.R. (1999) Biodegradation kinetics of napthalene, phenanthrene and pyrene. Biotechnology Bioengineering, 65, 491-499.

[7] Grady, C.P.L., Smets, B.F., Barbeau, D.S.(1996).Variability in kinetic parameters estimates. Water Research, 30, 742-748.

[8] Cerniglia, C.E. (1993). Biodegradation of Polycyclic aromatic hydrocarbons. Biodegradation, 4, 331-338.

[9] ] Cerniglia, C.E. (1992). Biodegradation of Polycyclic aromatic hydrocarbons. Biodegradation, 3, 351-368. 